This document is the accepted manuscript version of the following article:

Larsen, T. A., Maurer, M., Eggen, R. I. L., Pronk, W., \& Lienert, J. (2010). Decision support in urban water management based on generic scenarios: the example of Nomix technology. Journal of Environmental Management, 91(12), 2676-2687.

https://doi .org/10.1016/j.jenvman.2010.07.032

This manuscript version is made available under the CC-BY-NC-ND 4.0 1icense http:// creativecommons.org/1icenses/by-nc-nd/4.0/

\title{
DECISION SUPPORT IN URBAN WATER MANAGEMENT BASED ON GENERIC SCENARIOS: THE EXAMPLE OF NOMIX TECHNOLOGY
}

\section{Tove A. Larsen*, Max Maurer, Rik I. L. Eggen, Wouter Pronk, Judit Lienert}

Eawag, Swiss Federal Institute of Aquatic Science and Technology

8600 Dübendorf, Switzerland

*Corresponding author: Tel/Fax: +41 44823 5039/5389, E-mail: larsen@eawag.ch

\section{SHORT TITLE}

\section{Decision Support for Implementing NoMix Technology}

\section{ABSTRACT}

Urine source separation (NoMix technology) followed by processing the concentrated nutrient solution has the potential to become a cost-efficient alternative to conventional end-of-pipe nutrient elimination. A choice of processing technologies can only be made for specific scenarios, and there is currently no methodology for analyzing generic situations. In setting up a formalized decision-support methodology (based on STEEPLED analysis), we discuss how to create such generic scenarios, how to couple them with process engineering objectives, how to define the technology requirements, and finally how to produce a realistic subset of technology alternatives. The methodology is tested in five real scenarios. We also touch on the criteria for a final choice of technology taking into account large uncertainties about the performance of real technologies. We conclude that technology development is one of the most important requirements for implementing urine source separation in practice. There is an urgent need to develop cost-efficient processing technologies that satisfy the requirements of stakeholders. 


\section{KEYWORDS}

Wastewater, sustainability, urine, source separation, NoMix technology, STEEPLED.

\section{INTRODUCTION}

Urine source separation (NoMix technology) has the potential to become a costefficient (Maurer et al., 2005) and effective technology for water pollution control where nutrient elimination is of great importance (Larsen et al., 2001, 2009; Wilsenach and van Loosdrecht, 2006). Especially in view of the increasing importance of 'dead zones' in coastal areas (see e.g. UNEP, 2006) and the necessity of water recycling (see e.g. Oron et al., 2007), the importance of nutrient elimination is likely to increase in future (Larsen et al., 2007). Furthermore, depletion of phosphorus resources (Cordell et al., 2009) and the recent variations in fertilizer prices have also spurred interest in NoMix technology for nutrient recycling. The concept of urine source separation is very appealing to the general public, despite design-related drawbacks of existing NoMix toilets (Lienert and Larsen, 2010). However, considerable development is needed to fulfill all promises, and whether NoMix technology will actually become a viable and economically attractive alternative to more conventional wastewater treatment approaches will depend greatly on technical improvements to applicable solutions.

NoMix technology has been suggested in many versions. The most basic idea follows the traditional management of liquid manure in agriculture: local storage of urine and direct application on fields as a fertilizer (Hellström and Johansson, 1999). However, this approach may cause a number of unintended problems (Lienert and Larsen, 2007). 
Apart from the costs and space requirements of prolonged storage, these problems concern the environmental impacts of such a practice. First, there is a danger of shifting the nutrient problem from a controllable point source to an uncontrollable non-point source. Since urine comes in a fixed nutrient mix primarily made up of nitrogen, phosphorus, and potassium, raw urine will always contribute all these nutrients. This may be desirable in areas with a general and pronounced nutrient scarcity, but in most parts of the world it would be preferable to customize fertilizer application to the nutrient situation. Furthermore, human urine also contains contaminants: Micropollutants such as pharmaceuticals and hormones have given rise to concern because they pose a potential risk to agriculture (Escher et al., 2006; Lienert et al., 2007a, 2007b). For these reasons, processing options leading to the separation and purification of the nutrients in urine will dramatically extend the possibilities of NoMix technology compared with the application of raw urine after storage.

Maurer et al. (2006) have reported on the progress recently made in NoMix process engineering and present the main processing technologies available. It was shown that urine processing technologies can achieve several different goals. Although this diversity is an asset, it also makes specific choices difficult: Which technology is suitable? Is a combination of different technologies necessary, and what are the pros and cons of the various choices? Interest in NoMix technology is increasing and we receive many inquiries for advice from interested parties. Due to the flexibility of this technology, however, we cannot give such advice without knowing more about the specific situation (scenario) in which it will be applied. 
Some general advantages (as well as disadvantages) of NoMix over conventional technology have been shown by several authors (see Wilsenach et al., 2006 and Lienert and Larsen, 2007), but there is currently no specific tool for choosing between the many different processes. In this paper, we present a logical decision procedure that will help users choose the most appropriate urine processing technologies in NoMix projects. We focus on the structuring of the decision problem rather than on decision making itself. The core element of the methodology is the combination of a tool for market analysis, which allows for the construction of a generic scenario, and a structured technology analysis. To our knowledge, such a combination is not available from the literature.

We will not compare NoMix and conventional technologies. Moreover, the methodology does not cover the use of NoMix technology to optimize the central system, e.g. by peak shaving (Rauch et al., 2003) or in-house nitrification, in order to protect anaerobic sewers from corrosion (Oosterhuis and van Loosdrecht, 2008; for an overview of the role of nitrate to protect sewers against corrosion, see e.g. Yang et al., 2004). These exceptions are not caused by methodological limitations, but by a wish for clarity. In principle, our methodology can be used for any decision of relevance to wastewater treatment, but all tables and especially Figure 2 would have to be adapted accordingly. Please note that the methodology is not an expert system, but that the format allows people with a profound knowledge in different areas to communicate efficiently in order to structure a given decision problem, which again may lead to more insight. Especially for radical innovations like NoMix technology, such insights are extremely valuable. 
It is important to note that decisions on NoMix technology require not only a knowledge of the engineering and environmental aspects, but also of the stakeholders' preferences (see Borsuk et al., 2008 for a more detailed discussion). In order to conduct a meaningful analysis, it is not enough to state what one wants (from a technical point of view); one also has to know, from the stakeholders' perspective, why one wants to do it. Since it is not practical to conduct a detailed study of stakeholder preferences for every NoMix decision (e.g. with structured interviews as part of a formal multi-criteria decision analysis procedure; see Borsuk et al., 2008 for an example), we have developed a faster and more practical procedure that will still lead to transparent and informed choices. We also hope that the insights gained with this methodology will help direct research into and development of urine processing technologies. However, we would like to emphasize that only actual stakeholders with profound local knowledge can make such choices; our analyses are merely intended to help structure and inform these choices.

A schematic representation of the methodology is found in Figure 1. It includes a generic description of a given scenario ${ }^{1}$ (step 1), leading to a number of urine processing objectives in this scenario (step 2). On the basis of these objectives, we list a number of suitable technologies (or combinations thereof) that will satisfy the objectives (step 3). These (combinations of) technologies can then be evaluated with respect to a list of criteria (step 4) and finally ranked according to the preferences of the stakeholders in the given scenario (step 5). Note that step 3 is a preliminary

\footnotetext{
${ }^{1}$ We use the word scenario for any description of a case application
} 
screening that allows for the exclusion of certain technologies, which would significantly reduce the efforts necessary in step 4 . Step 3 also identifies the necessary process combinations (including post-treatment steps such as hygienization) in order to ensure that only complete process combinations are compared in step 4 .

In this paper, we first develop the methodology (Section 2) and then apply it in five selected scenarios (Section 3). At the present state of development of NoMix technology, it is practically impossible to apply steps 4 and 5 in an actual scenario because most technologies are still very immature. We therefore only discuss these steps qualitatively.

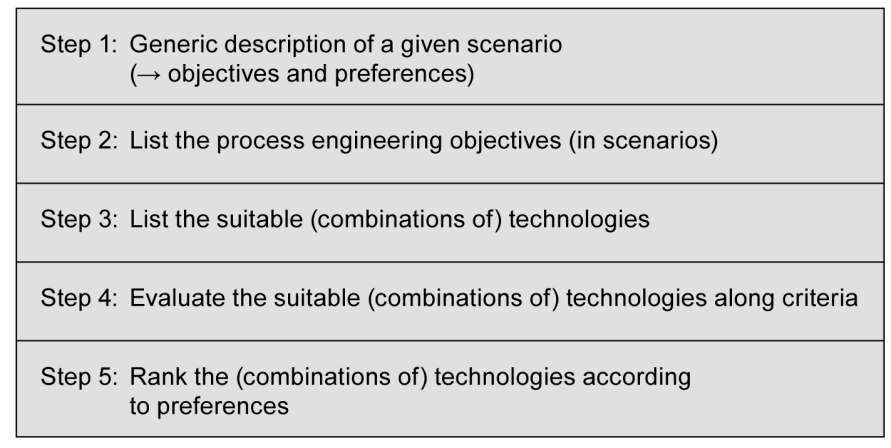

Figure 1. The five steps of the methodology presented in this paper. Possible starting points are step 1 and step 2 , and one will naturally want to end with step 4-5. We would like to emphasize, however, that the procedure is generally iterative.

\section{Methodology}

Decision analysis is inherently an iterative process that may require several cycles to be run through in order to better understand the decision context (Clemen and Reilly, 2001). It can be of advantage to begin with the steps that are best understood. In order to develop our methodology, we therefore begin with steps 2 and 3, where we have our main expertise. This also ensures that we keep the technical focus intended in the methodology and do not concentrate too much on social factors that may be 
interesting but are not significant for the choice of technology. We then return to step 1 and develop a generic scenario that allows the relevant process engineering objectives to be derived. From a methodological point of view, steps 4 and 5 are rather straightforward and will therefore only be discussed briefly in the Methodology section. Many existing methods can be used for comparing quantitatively the possible alternatives such as Multi-Criteria Decision Analysis (excellent introduction to MCDA for non-decision analysts in Keeney, 1982). In the context of NoMix technology some possibilities were discussed in Borsuk et al. (2008).

Step 2 (our preferred starting point for developing the methodology): List the process engineering objectives in a given scenario

Before we take on the stakeholders' point of view in a given scenario, we analyze which objectives can actually be realized with NoMix technology and urine processing. We base our analysis on the combined experience of the authors in the cross-cutting Eawag Novaquatis project that ran from 2000-2006

(www.novaquatis.eawag.ch). Taking our point of departure in the services offered by urban water management (Larsen and Gujer, 1997), we identify the following four drivers of NoMix technology in a given scenario: water pollution control, nutrient recycling, water recycling, and hygiene. As a driver we define a factor that influences or determines whether NoMix technology is applied or not. The drivers may also influence how NoMix technology is implemented. In this step, we deliberately concentrate on the services that can be delivered by NoMix technology and not on the drivers that will motivate individual stakeholders to take action. Although the recent surge in fertilizer prices, for example, is naturally a potent driver for increased interest in nutrient recycling, such aspects will be dealt with in a later step. Likewise, 
enhancing the flexibility of the wastewater system is another major factor, but again this is a question of stakeholder perception and not of a specific service provided by NoMix technology.

The process engineering objectives of NoMix technology can be derived from these various drivers on the basis of the main components of urine (Table 1; Udert et al., 2006).

Table 1 Composition of urine (Udert et al., 2006)

\section{Driver: Water pollution}

This aspect refers to the following substances in urine: nitrogen, phosphorus, organic micropollutants (MPs), and for arid areas possibly also salt. Potassium, micronutrients, heavy metals, and microorganisms from urine are normally not considered of any importance for water pollution. Although COD from urine makes up about a third of soluble organic matter in wastewater, we do not consider it to be a relevant objective for urine processing technology. For simplicity, we will only consider the removal of $\mathrm{N}, \mathrm{NH}_{3} / \mathrm{NH}_{4}{ }^{+}, \mathrm{P}$, and $\mathrm{MP}$ as objectives in this paper.

\section{Driver: Nutrient scarcity}

This aspect refers to N, P, K, and micronutrients. For simplicity, we will only consider the recovery of the two most important macronutrients, namely nitrogen and phosphorus, as objectives in this paper. For every recovery option, quality requirements for the fertilizer product must also be considered. We will concentrate on the following quality aspects: hygiene, MPs, and salt content. For 
simplicity, we will refer all other requirements relating to fertilizer quality to the criteria list, such as smell or whether the nutrients are obtained in liquid or solid form (see step 4). Microorganisms and MPs can either be eliminated or merely separated from the nutrients. Since we do not consider hygiene for the fraction of urine that is discharged to the receiving water, we do not distinguish between removal and separation of microorganisms. With regard to salinity we will only consider whether the salt fraction is found in the fraction containing the nutrients or not.

\section{Driver: Water scarcity}

This aspect refers to the possibilities of water recycling (urine separation to facilitate the reclaiming of wastewater), savings of toilet flush water, and in extreme situations such as in a space shuttle, even the wish to recover the water content of urine. Whereas the two latter topics are quite straightforward, water recycling is only indirectly influenced by NoMix technology. The absence of nutrients and salts stemming from urine will normally simplify the treatment. In biological systems, for example, nitrification/denitrification will not be necessary, and the lower salt content of wastewater without urine will be favorable for membrane processes such as reverse osmosis. Interestingly, no process engineering objectives can be derived from this driver except for the extreme situation in a space shuttle, which we do not consider here. Thus, in the absence of any concomitant requirements related to environmental pollution or nutrient scarcity, the obvious approach is to look for the cheapest way of getting rid of the urine, e.g. by infiltration. This is, incidentally, the most common 
means of dealing with source-separated urine in Africa (Anonymous, 2005). Nevertheless, water scarcity is an important driver for the implementation of NoMix user-interface and collection systems.

\section{Driver: Hygiene}

Although urine plays no direct role for hygiene in a residential area, NoMix technology can still be motivated by reasons of hygiene. In areas lacking an effective solution to the hygiene problems of combined wastewater, urine separation can be part of a source-separation strategy that relies on the separate treatment of feces, urine, and grey water (see Kvärnström et al., 2006). As for driver 3, we do not identify any specific process engineering objectives from this driver.

From the four drivers of NoMix technology, we have thus identified the following process engineering objectives: REMOVAL of ammonia, nitrogen, phosphorus, MPs, (and salt); RECOVERY of nitrogen, phosphorus, (and further nutrients);

SEPARATION of nutrients and MPs in fertilizers; and HYGIENE of an obtained fertilizer product. For simplicity, the issues in brackets will not be discussed in any detail in this paper.

Step 3: List the range of suitable (combinations of) technologies in a given scenario Maurer et al. (2006) list and describe a large number of process options. In Figure 2 and Table 2 (with explanatory notes), we allocate these technologies to the process engineering objectives identified above. In the REMOVAL matrix (Figure 2a), we distinguish between the removal of ammonia $\left(\mathrm{NH}_{3} / \mathrm{NH}_{4}{ }^{+}\right)$, nitrogen $(\mathrm{N})$, and MPs. In contrast to $\mathrm{NH}_{3} / \mathrm{NH}_{4}{ }^{+}, \mathrm{N}$ and MP, phosphorus (P) can in principle not be eliminated 
(in the sense of being destroyed or transformed into an unproblematic compound like $\mathrm{N}_{2}$ ), and there is consequently no specific process of removing $\mathrm{P}$ from urine. All relevant processes for $\mathrm{P}$ can lead either to its removal (with its subsequent storage or disposal) or to its recovery (and subsequent recycling). For simplicity, therefore, we show the P-processes only in the RECOVERY matrix.

In the RECOVERY matrix (Figure 2b), we mainly distinguish between the recovery of N, P, and N+P. Furthermore, we indicate whether the HYGIENE requirements for a fertilizer product can be achieved by optimizing the process and whether SEPARATION between MPs and nutrients takes place. We also indicate whether the salt content of urine is found in the fertilizer or in the waste part of the urine, but do not discuss this aspect in any detail. Due to the extensive lack of data about the effect of treatment options on hygiene parameters, there are large uncertainties with respect to this quality requirement. We therefore take a simplified approach. Treatment processes are qualified as hygienization if there is a high certainty that they can be optimized to reach a given level of hygiene. Thus ozonation can be optimized to achieve a specific pathogen reduction. A stricter definition of hygienization would require a risk analysis, such as that performed by Höglund et al. (2002) for using collected urine in agriculture. The World Health Organization recommends a health protection level of $\leq 10^{-6}$ DALY (disability adjusted life years) per person per year (for more details see WHO, 2006). Note that in most cases the hygiene target can be achieved with a post-treatment step, but this has to be included in the evaluation in step 4. There is at present no definition of 'good enough' for MP removal or separation from nutrients. So we merely indicate whether a given process influences MPs or not. The original literature, which is referenced in Maurer et al. (2006), should 
be consulted for information on the present state of knowledge about process efficiency with respect to MP. In Table 2, we list the recovery and removal options together with explanatory notes. For completeness, we include the options in which removal can be obtained by recovering and subsequently disposing of the dry nutrient product - this could be of importance in cases such as where the fertilizer is not approved for application. Note that Maurer et al. (2006) do not discuss the aspect of disposal of a potential fertilizer product. Alternatively, nutrients can be recuperated as raw material for the fertilizer industry, but there is currently no such established route of nutrient recycling.

We restrict our choice to the technologies about which more detailed information and further references can be obtained in Maurer et al. (2006). Removal and recovery objectives may, of course, be freely combined (e.g. removal of ammonia combined with recovery of phosphorus). We do not list all these possible combinations in Table 2, but only those that result naturally from the choice of a specific technology, i.e. the large number of technologies that lead to simultaneous removal or recovery of $\mathrm{N}$ and P.

Table 2 Generalized overview of the various options for urine: removal, recovery, hygienization, separation of micropollutants and removal of micropollutants (see also Figure 2) 
$2 a$ Removal Matrix

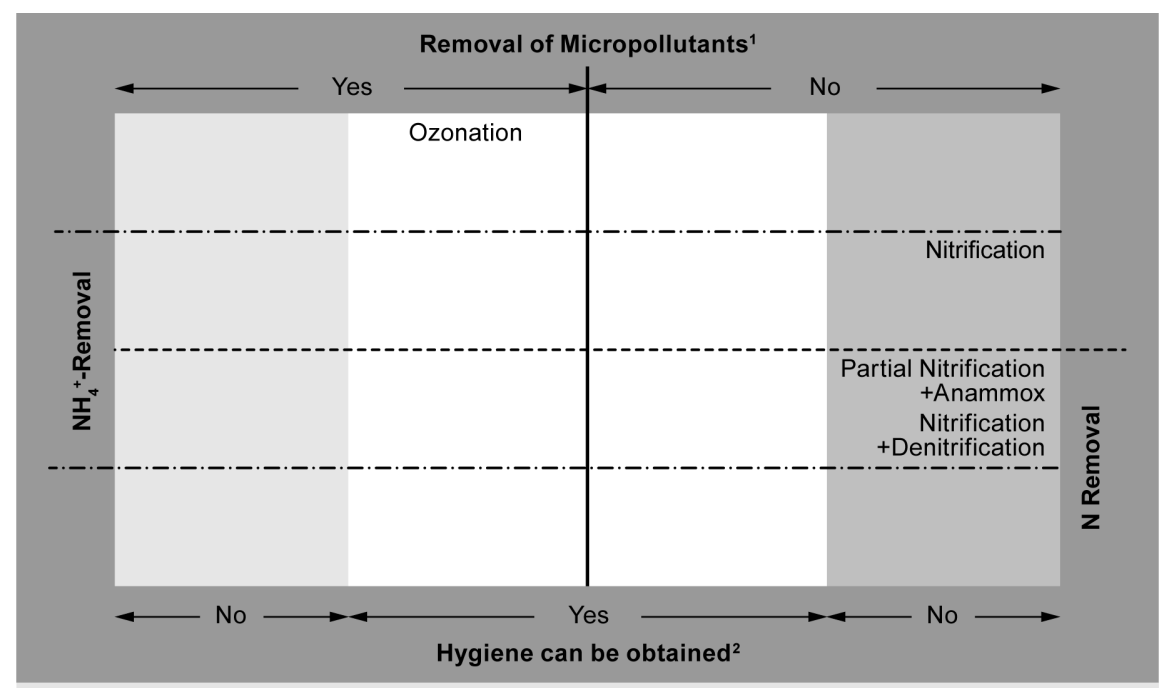

2b

Recovery Matrix

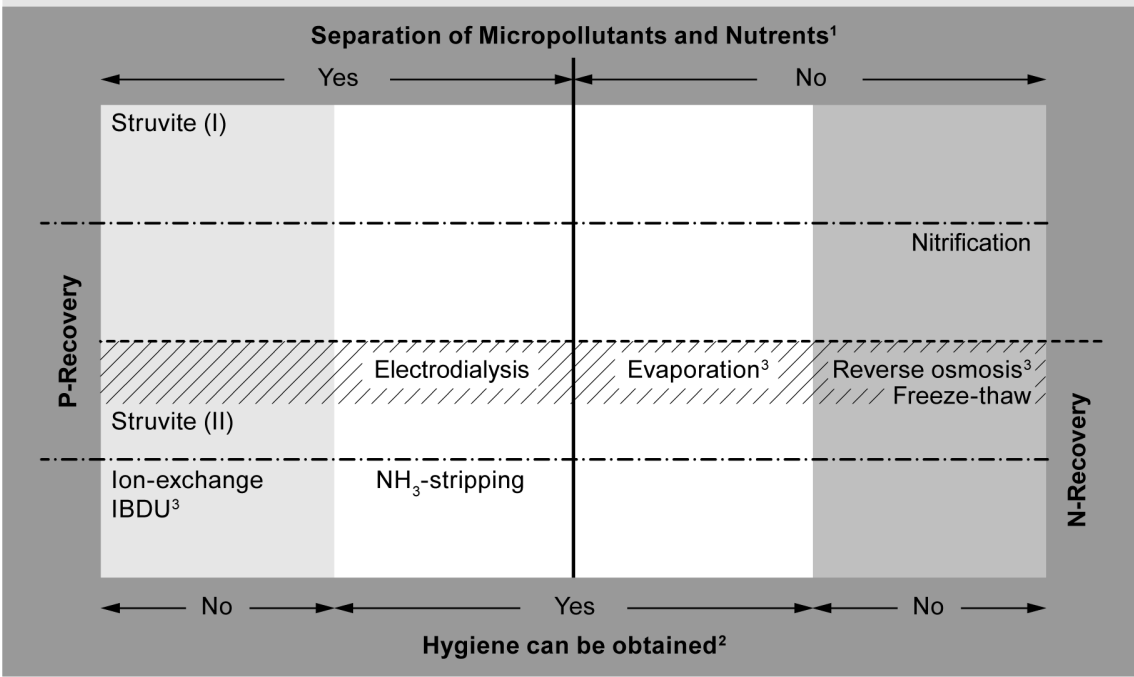

2c

Other Treatments

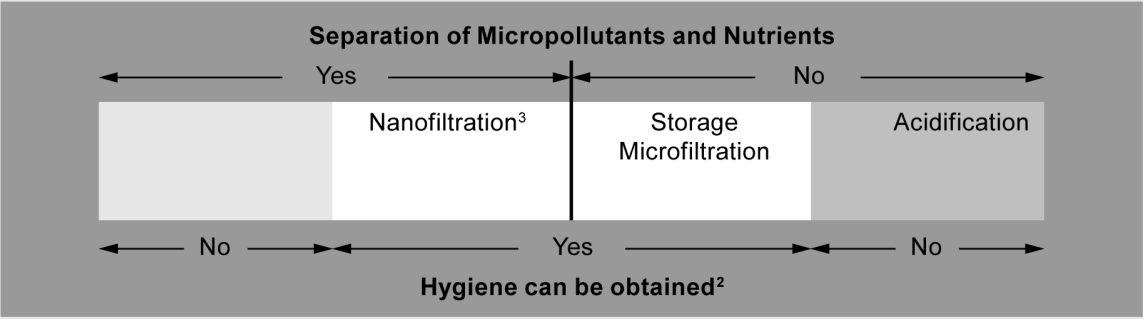

DIA Salt contained with nutrients (see definition and discussion in text)

${ }^{1}$ For separation and removal efficiencies for micropollutants, see Maurer et al. (2006)

${ }^{2}$ We consider that these processes can be optimized to fulfill reasonable hygienic requirements

${ }^{3}$ Requires pre-treatment in form of acidification, see Table 2 for details

Figure 2. REMOVAL (2a) and RECOVERY (2b) matrix for urine processing technologies

OTHER TREATMENTS in Figure 2c. For explanatory notes, see Table 2. All technologies are described in Maurer et al., 2006; with further references to the original publications. 


\section{Step 1: Generic description of scenarios}

After having developed steps 2 and 3 of the procedure, we return to step 1 . In order to describe the scenarios in a generic way, we chose the STEEPLED analysis, which is a common tool for market analyses. This analysis - originally known as the PEST analysis (see e.g. Griffiths and Wall, 2004, for a textbook coverage of the methodology) - is used to describe the external forces that a private business must typically consider and cannot influence by itself. PEST stands for Politics, Economy, Sociology, and Technology. The acronym STEEPLED results when one includes Ecology, Legal issues, Ethics, and Demography as independent factors. With the STEEPLED tool, we develop a generic description of scenarios that will allow plausible objectives to be identified in actual scenarios. At this stage of the methodology development, we list all possible outcomes (= main states) of the factors. Once the methodology has been established, however, a specific scenario will only consist of a subset of these factor outcomes (see Section 3).

In Table 3, we list the most important factors for understanding the decision to apply urine processing technology. The list is based on the combined experience of the authors gained in the cross-cutting Eawag Novaquatis project

(www.novaquatis.eawag.ch). In column 1, we list the relevant STEEPLED factors; in column 2, we list the main states that these factors can assume; in column 3, we translate these states into process engineering objectives (only where possible); and in column 4, we comment on the influence of the different states on the weighting of the criteria in step 5 (again where possible, see below). Note that in most cases the objectives derived from the STEEPLED factors will seem contradictory; it is very seldom that something is required from all points of view. For example, a certain 
action can be very plausible from a legal point of view, but not from the perspective of specific problems experienced at the location - or the other way round. Such apparent contradictions appear in all of our scenarios. It is important to accept that stakeholders argue from different points of view and also that different factors have different levels of uncertainty. While the legal aspects are normally clear - thus it is easy to establish whether there is a target for N-elimination or not - ecological aspects, for example, may be judged differently by different stakeholders. The formalized STEEPLED presentation helps to clarify the various stakeholder positions.

Table 3 NoMix STEEPLED factors for a generic description of the scenarios. We list the factors that may play a role in deciding which NoMix technology is best in a given scenario. The main state of the factors that influence the process engineering objectives is indicated in bold. For explanations see text.

\section{Step 4: Evaluate suitable (combinations of) technologies along a range of criteria}

The criteria were developed independently by practice partners of Novaquatis who carried out their own NoMix implementation project in a public library (Boller, 2007; Pronk et al., 2007) and the authors, respectively. There was a large degree of agreement between the two lists, which convinced us that a combined list offers a good basis for evaluating urine processing alternatives (Table 4). We do not rank the criteria, but in Table 3 we have pointed out the more evident influences of the STEEPLED factors on such a weighting. Obviously, this can merely be a qualitative evaluation; only real stakeholders can express their preferences quantitatively.

Table 4: Stakeholder criteria for evaluating urine processing technologies 
Step 5: Rank suitable (combinations of) technologies according to preferences As stated above, processing technologies for urine treatment are in most cases too immature to allow a meaningful evaluation. We therefore omit a discussion of this last step. However, we would strongly recommend that actual technology developments are always combined with an evaluation of the issues listed in Table 4. One example of evaluation of the energy consumption of different NoMix process engineering technologies is found in Maurer et al. (2003).

\section{Scenarios}

We chose the following five scenarios (Scenario 1-Scenario 5), three of them in Switzerland, one in China, and one in Australia. We have worked with stakeholders from Scenario 1-Scenario 4, whereas Scenario 5 is based on an eco-village in Queensland and the information was obtained from the coordinator of this pilot project (Beal et al., 2008; Beal, 2008).

\section{Scenario 1 Overloaded WWTP CH}

A new residential area in a catchment with an overloaded nitrifying wastewater treatment plant (WWTP; described in detail by Borsuk et al., 2008).

Because a new residential area will be built locally over the next 15 years, an existing treatment plant will reach its capacity limit during this period on the basis of the legal requirements for $\mathrm{N}$ and ammonia emissions. If the urine from the new residential area is used for peak shaving (leveling out the nitrogen peak) in the treatment plant, an investment of CHF 10 million (about $€ 7$ million) could be postponed for 7 years. On the basis of the preferences of the stakeholders involved, however, it makes sense to expand the NoMix technology to the entire catchment 
area over the next 20 years in order to process the urine separately and run a compact treatment plant for COD-removal only (for more information on the advantages of this option, see Wilsenach et al., 2006). For this outcome, the precautionary principle with respect to avoiding MPs in the environment plays a role, but nutrient recycling is only of minor importance. This can thus be seen as a transition scenario that leaves open future options in the event that society places more weight on environmental issues (Borsuk et al., 2008).

\section{Scenario 2 Holiday resort $\mathrm{CH}$}

A ski resort with large fluctuations in population pressure.

Scenario 2 is motivated by the strong and rapid variations in wastewater load occurring in a ski and vacation resort, which cannot be dealt with by a conventional biological nitrifying treatment plant (Abegglen and Haag, 2002). At the onset of the winter season, the load on the WWTP increases by a factor of seven. Additionally, there are strong weather-dependent variations during the week due to day visitors. The strong variability of the wastewater load exceeds the adaptability of the biological nitrification process, independently of the size of the WWTP. Due to the economic importance of an 'intact' environment, the situation is generally considered unsatisfactory. In personal discussions, decision-makers pointed out that (global) sustainability problems are caused by urbanization and that the risky introduction of innovative technology should be made in metropolitan areas, and not in the mountains. Hence, they are mainly interested in a shorter-term solution to their ammonia-peak problem rather than in long-term options for nutrient recycling or micropollutant elimination. The situation of 
strong temporal ammonia peaks is found in many tourist areas all over the world and is not restricted to Alpine winter resorts.

\section{Scenario 3 Hospital $\mathrm{CH}$}

A hospital/ home for the elderly in Switzerland.

The situation in Scenario 3 differs completely from that in Scenario 2. The interest here is not motivated by any immediate environmental or legal pressures. The important driver is the precautionary principle (reducing possible risks of MPs from hot spots like hospitals and homes for the elderly) as well as the expectation that it may be of economic advantage in future to be able to remove MPs from hot-spots at source. Initially, the possibility of closing the nutrient cycle was also important, but ongoing interviews with the stakeholders conducted by J. Lienert have revealed that nutrient recovery has in the meantime become a secondary priority compared to the issue of MPs. These recent follow-up studies indicate that hospital waste streams can indeed be ecotoxicologically relevant point sources (Escher et al., in rev.) and that Swiss hospital stakeholders are rather concerned about MPs (Lienert et al., in prep., Schuwirth et al., in prep.). This scenario is based on the pilot projects described by Pronk et al. (2007) and Boller (2007), but was modified by new information on stakeholder perception (Lienert et al., in prep.).

Scenario 4 A fast-growing city in China in the catchment of a P-sensitive lake In Chinese Scenario 4, the interest in NoMix technology is mainly based on controlling water pollution. In addition, the farmers in the area are interested in locally available nutrients. Our scenario is based on a Novaquatis cooperation 
project with the city of Kunming, a booming capital near Lake Dianchi, which has excessive phosphorus levels. There are strong economic incentives for restoring the lake and measures at source are deemed necessary due to high population pressure from the rapidly growing metropolitan area (Medilanski et al., 2006, 2007; Huang et al., 2007). In view of all these substantial problems, sustainability and the precautionary principle are not explicit factors in choosing the NoMix technology. Whereas simple solutions for rural areas with direct spreading of urine on agricultural land are already being implemented and are not discussed here (see Medilanski et al., 2007), possible scenarios for the greater metropolitan area are not at all clear.

\section{Scenario 5 An eco-village in Australia (Beal, 2008; Beal et al., 2008)}

A pilot project on urine source separation is being run in the eco-village of Currumbin (Queensland, Australia) to test the practicability of NoMix technology. Closing the nutrient loop in order to mimic the natural cycles in an urban settlement is an important philosophical justification for the project, but there is no explicit concern over a shortage of phosphorus. Nitrogen and phosphorus are considered a problem for the aquatic environment and legal targets have been set. However, no problems are being experienced with the efficiency of the existing sewer system and treatment plants. The politicians are generally helpful and interested, but regulators have more concerns. The problem of MPs is high on the agenda of some of the parties involved, but it has not been possible to obtain any information on the hygiene requirements of a fertilizer product. 


\section{Applying the Decision Methodology in Five Different Scenarios}

Step 1: Generic description of a given scenario

We specifically characterize each of the five scenarios along the generalized STEEPLED analysis from Table 3 and present them in Table 5.

Table 5 Generic description of the five chosen scenarios based on a STEEPLED analysis

Step 2: List the process engineering objectives in a given scenario

Combining Table 3 and Table 5 leads to a number of scenario-specific process engineering objectives as listed in SI, Table 1. In order to maintain the overview, we only list the STEEPLED factors that directly influence the process engineering objectives (all details are found in Table 5).

Step 3: List the range of suitable technologies or combinations in a given scenario On the basis of SI, Table 1 and Figure 2/Table 2, any process engineer can select the urine treatment technologies possible for a given scenario. An inherent complication is the possibility that technologies achieving more than the minimum requirements in the scenario may be preferable to the stakeholders for some other reasons (e.g. because they are actually cheaper or more robust). More experience with the technologies is required before this aspect can be intelligently discussed. As an example, we list the approximately thirty different technical alternatives available for Scenario 1, an overloaded wastewater treatment plant in Switzerland (SI, Table 2).

Step 4 / Step 5 
As already discussed, too little information is available on the actual technologies to perform steps 4 and 5 in any meaningful way. We illustrate this with a qualitative comparison of three technologies that have been or are being seriously discussed by the stakeholders involved in Scenario 1. There is no need to compare all thirty technologies listed in SI, Table 2 in order to show that informed choices are currently still very difficult. Both removal and recovery options have been discussed, although only removal is a stakeholder priority. The three technologies are:

(I) Nitrification + denitrification (with methanol)

(II) Partial nitrification + anammox (Udert et al., 2008)

(III) $\mathrm{NH}_{3}$ stripping with capture of $\mathrm{NH}_{3}$ in sulfuric acid

None of these technologies takes phosphorus into account because the technical implementation of P-removal at the treatment plant does not really involve any complications. It is obvious that all these technologies have been suggested because they are already used or considered for treating sludge supernatant. Engineers tend to prefer incremental innovations, an approach that depends on the path of technical development. Since ozonation for the removal of MPs is in principle possible in all three cases and there would be no problem in installing such a technology later on, it is reasonable to postpone any decision concerning this option. We will therefore compare these three technologies without ozonation along our list of criteria (Table 6).

From the ongoing discussions amongst stakeholders and engineers on these three technologies, we have observed that the most critical factors for actual implementation are costs and the assessment of the robustness of the technology. 
When fertilizer prices were still low, biological removal was favored, and it was clear that most practical engineers involved in the discussions would prefer the robust and well-known nitrification/denitrification scheme. In the meantime, more experience had been gained with nitritation/anammox, and fertilizer prices had (temporarily) risen at the same time, leading to strong interest in the stripping process. Ongoing work concentrates on minimizing the resources involved in ammonia stripping, but the robustness of the process is expected to be good. However, the most convincing argument for all three technologies is their flexibility. One of these technologies may well be installed anyway in order to treat sludge supernatant, and the option of adding urine to an existing central treatment is obviously attractive.

Table 6: Qualitative comparison of three technologies considered for Scenario 1.

\section{Discussion}

In this paper, we present a model of decision making for urine treatment technology. Like any model, it only tries to approximate reality by highlighting the most important aspects of the decision process. And like any model, it permits modifications - real stakeholders may have concerns that are not anticipated in this generalized approach. However, it is important to capture the main idea of the framework: There must be a logical translation of stakeholders' perspectives into practical process engineering objectives. If, for example, one perspective were merely 'sustainability', no such logical translation step exists, and we must consequently try to define our perception of what is sustainable. Likewise, urine processing technology cannot solve problems unrelated to urine. For example, a wish for urban hygiene (where the problems are mainly caused by feces), does not automatically translate into any hygienic 
requirements related to the handling of urine or a urine-based fertilizer. Nevertheless, urban hygiene may be a driver for urine source separation because this technology facilitates the safe handling of feces. Furthermore, the distinction between the individual STEEPLED factors is not always evident. For example, is water scarcity a social, ecological or economic aspect? We have chosen to highlight the social aspect because this is normally the dominating perspective when water scarcity is discussed amongst professionals in urban water management. However, there may be scenarios where either the economic or the ecological perspective dominates, and there are, of course, no methodological problems at all in adopting a different view and moving the water scarcity aspect to another category. Some people also have difficulties with the distinction between legal and ecological aspects with respect to nutrient or MP emissions. The general idea is that legal aspects mirror social demands: If there is a perceived problem, there will also be a legal target (actually, we made this assumption ourselves in the Kunming case). Unfortunately, this is far from always being the case. Typical examples are well known and omnipresent: delays in the legislative process, other topics are favored, an incompetent political elite, etc. The distinction between legal and ecological aspects enables us to capture the aims of certain stakeholders who may perceive a problem which has not been noted sufficiently (or at all) by the authorities or a majority of the population. For a meaningful discussion, it is important to pinpoint the different views of the stakeholders involved, and the various perspectives highlighted by the framework help to achieve this.

We also have to accept uncertainty. For example, our framework does not intend to give some arbitrary definition of the word 'problem'. This definition must necessarily be left to the stakeholders involved. Consequently, we cannot be 'right' about every 
stakeholder's perception without conducting detailed interviews with all the main stakeholders. In practice, resource limitation prohibits this approach (see Borsuk et al., 2008, Lienert et al., in prep., and Schuwirth et al., in prep to get a realistic idea what stakeholder interviews involve). Our methodology represents a shortcut, allowing the stakeholders to rapidly figure out amongst themselves whether they agree on the basic assumptions or not. If all stakeholders are asked to fill in Table 5 for a given scenario, any disagreement will be apparent from the different aspects filled in (e.g., one stakeholder may be of the opinion that there is a legal target for phosphorus, whereas the other stakeholders think that there is none).

We also find this method very helpful when it comes to discussions with stakeholders who have less experience in urban water management. If, for instance, an agency considers recycling for ethical reasons and some of the stakeholders think this is based on economics, i.e. the monetary value of fertilizer, these stakeholders may have good grounds to feel deceived in the end. Obviously, we have not covered all possible motivations for urine source separation in this paper - actual stakeholders will be able to suggest their own. For instance, our scenarios contain no examples in which the ethical aspect of 'solidarity' plays an explicit role. Nevertheless, such a motivation is highly realistic, e.g. in eco-villages, where people are keen to help develop technologies that could mitigate serious problems in other parts of the world. We have no intention of claiming that only our STEEPLED factors are rational; they just cover a reasonably large set of possibilities and we have information on them from the scenarios that we have examined. 
It is also clear that our analysis will not be valid indefinitely. For example, organic MPs from urine are currently only of concern from the point of view of the precautionary principle. However, this could change very rapidly; it is already conceivable that legal requirements could be imposed, especially for hospital wastewater. New scientific evidence could also bring to light the ecological problems caused by MPs. Perhaps the most striking result of our analysis is what we were unable to do. Although we are well able to analyze what stakeholders may want and how the different technologies could be evaluated, there is a tremendous lack of knowledge about currently feasible technologies. We did try to evaluate the technologies along the criteria in Table 4, but the large uncertainties forced us to limit this task to a small qualitative analysis within a scenario. This is an unavoidable and inherent characteristic of a very early development stage of any technological innovation.

However, we also see how quickly real-world boundary conditions can change. Whereas we used to look at nitrogen recovery mainly from an energy point of view (Maurer et al., 2003) and have retained this perspective in the present paper, the rise of fertilizer prices (USDA, 2009) may act as a much stronger driver for attempting to recover nitrogen. Although energy is still the basic issue, the motivation for nitrogen recovery recently shifted from being mainly ethical to becoming essentially economic; a fact that will probably not be changed by the momentarily decreasing energy prices. Although this means that our framework is subject to continuous changes, we still hope that it can provide some clues for analyzing the needs and requirements for relevant technology developments. 


\section{CONCLUSION}

The methodological framework that we have built up in this paper works well for organizing the decision process of technology choice in different scenarios, where NoMix technology would be implemented. The clarity gained in the process allows for more target oriented research and development of urine processing technology and it also emphasizes the many different contexts, where NoMix technology would be suitable. Similarly, such an analysis will also help avoid frustration arising from different expectations amongst stakeholders involved in the process.

Since the methodology emphasizes the structuring of the decision problem and leaves it up to the decision makers how they would like to compare actual alternatives arising from the process, the lack of practical recommendations is not really critical for the message conveyed in this paper. In practice however, we are desperately in need of elegant, low-cost, efficient technologies that can satisfy the requirements of any stakeholders, irrespective of whether they want nutrient recovery or removal. Our qualitative example shows that the technologies for treating sludge supernatant represent good practical possibilities of pioneering technologies. We hope that the present paper will inspire other researchers to dive into the fascinating world of NoMix technology, and help develop technology, which will appeal to a large range of interested stakeholders.

\section{ACKNOWLEDGEMENTS}

We thank Eawag for funding and our practice collaborators for providing and financing the case studies as well as sharing with us their insights into the difficulties 
of implementing NoMix technology. We also thank two anonymous reviewers for their constructive comments.

\section{REFERENCES}

Abegglen, C., Haag, S., 2002. Nitrifikationskapazität der ARA Arosa. Diploma thesis at the Institute of Environmental Engineering, ETHZ, Switzerland. In German.

Anonymous, 2005. Ecosan: In search of a sustainable sanitation solution. Water Wheel, 4(4), $22-24$.

Beal, C., Gardner, T., Ahmed, W., Walton, C., Hamlyn-Harris, D., 2008. Urineseparation and reuse trials. Water 35(1), 66-69.

Beal, C., 2008. Personal communication Dr. Cara Beal, coordinator of NoMix pilot project in Queensland, Australia; Scientist (Urban Water), Department of Natural Resources \& Water, Indooroopilly Queensland 4068, www.nrw.qld.gov.au (Cara.Beal@nrw.qld.gov.au).

Boller, M., 2007. Fertilizer from the library. Eawag News 63, 17-19.

Borsuk, M.E, Maurer, M., Lienert, J., Larsen, T.A., 2008. Using decision analysis to chart a path for innovative toilet technology. Environ. Sci. Technol. 42(6), 1855-1862.

Clemen, R.T., Reilly, T., 2001. Making Hard Decision with DecisionTools®. $2^{\text {nd }}$ rev. ed.. Duxbury, Brooks/Cole, Thomson Learning ${ }^{\mathrm{TM}}, \mathrm{CA}, \mathrm{USA}, \mathrm{pp} .733$.

Cordell, D., Drangert, J.-O., White, S., 2009. The story of phosphorus: Global food security and food for thought. Glob. Environ. Chang. 19 (2), 292-305. 
Escher, B.I., Pronk, W., Suter, M. J.-F., Maurer, M., 2006. Monitoring the removal efficiency of pharmaceuticals and hormones in different treatment processes of source-separated urine with bioassays. Environ. Sci. Technol. 40(16), 5095-5101.

Escher, B.I., Baumgartner, R., Koller, M., Treyer, K., Lienert, J., McArdell, C.S., in revision. Environmental toxicology and risk assessment of pharmaceuticals from hospital wastewater. Water Res.

Griffiths, A., Wall, S., 2004. Economics for business and management. A student text. Pearson books. 027368549X (paperback). 776 pages.

Hellström, D, Johansson, E., 1999. Swedish experiences with urine separating systems. Wasser und Boden 51(11), 26-29.

Höglund, C., Stenstrom, T.A., Ashbolt, N., 2002. Microbial risk assessment of sourceseparated urine used in agriculture. Waste Manage. Res. 20, 150-161.

Huang, D.-B., Bader, H.-P., Scheidegger, R., Schertenleib, R., Gujer, W., 2007. Confronting limitations: New solutions required for urban water management in Kunming City. J. Environ. Manage. 84(1), 49-61.

Keeney, R.L., 1982. Decision analysis - an overview. Oper. Res. 30(5), 803-838.

Kvärnström, E. and 11 further authors, 2006. Urine diversion: one step towards sustainable sanitation. EcoSanRes Publication Series. Report 2006-1. Stockholm Environment Institute. Web download: http://esa.un.org/iys/docs/san lib_docs/Urine Diversion 20061\%5B1\%5D.pdf (accessed 23.06.2010)

Larsen, T. A., Gujer, W., 1997. The concept of sustainable urban water management. Water Sci. Technol. 35(9), 3-10. 
Larsen, T.A., Maurer, M., Udert; K.M., Lienert, J., 2007. Nutrient cycles and resource management: implications for choice of wastewater treatment technology. Water Sci. Technol. 56(5), 229-237.

Larsen, T.A., Peters, I., Alder, A., Eggen, R., Maurer, M., Muncke, J., 2001. Re-engineering the toilet for sustainable wastewater management. Environ. Sci. Technol. 35(9), 192A-197A.

Larsen, T.A., Alder, A.C., Eggen, R.I.L, Maurer, M., Lienert, J., 2009. Source separation: Will we see a paradigm shift in wastewater handling? Environ. Sci. Technol. 43(16), 61216125

Lienert, J., Bürki, T., Escher, B.I., 2007a. Reducing micropollutants with source control: Substance flow analysis of 212 pharmaceuticals in feces and urine. Water Sci. Technol. 56(5), $87-96$.

Lienert J., Güdel, K., Escher, B.I., 2007b. Screening method for ecotoxicological hazard assessment of 42 pharmaceuticals considering human metabolism and excretory routes. Environ. Sci. Technol. 41(12), 4471-4478.

Lienert, J., Larsen, T.A., 2007. Soft paths in wastewater management - the pros and cons of urine source separation. Gaia 16(4), 280-288.

Lienert, J., Larsen, T.A., 2010. High acceptance of urine source separation in seven European countries: A review. Environ. Sci. Technol. 44(2), 556-566.

Lienert, J., Konrad, J., Schuwirth, N., in preparation. How to deal with pharmaceuticals in hospital wastewater: A Multi-Criteria Decision Analysis (MCDA) involving many stakeholders.

Maurer, M., Pronk, W., Larsen, T.A., 2006. Review: Treatment processes for source separated urine. Water Res. 40, 3151-3166. 
Maurer, M., Rothenberger, D., Larsen, T.A., 2005. Decentralised wastewater treatment technologies from a national perspective: At what cost are they competitive? Water Sci. Technol.: Water Supply 5(6), 145-154.

Maurer, M., Schwegler, P., Larsen, T.A., 2003. Nutrients in urine: energetic aspects of removal and recovery. Water Sci. Technol. 48(1), 37-46.

Medilanski, E., Chuan, L., Mosler, H.-J., Schertenleib, R., Larsen, T.A., 2006. Wastewater management in Kunming, China: a stakeholder perspective on measures at the source. Environ. Urban., 18(2), 353-368.

Medilanski, E., Chuan, L., Mosler, H.-J., Schertenleib, R., Larsen, T.A., 2007. Identifying the institutional decision process to introduce decentralized sanitation in the city of Kunming (China). Environ. Manage. 39(5), 648-662.

Oosterhuis, M., van Loosdrecht, M.C.M., 2008. Nitrification of urine for $\mathrm{H}_{2} \mathrm{~S}$ control in pressure sewers. Proceedings of the International IWA Conference 'Sanitation Challenge: New Sanitation Concepts and Models of Governance', Wageningen May 19-21, 2008. Part 2 Poster Presentations, 101-106.

Oron, G., Gillerman, L., Bick, A., Mnaor, Y., Buriakovsky, N., Hagin, J., 2007. Advanced low quality waters treatment for unrestricted use purposes: imminent challenges. Desalination, 203(1-3), 189-198.

Pronk, W., Zuleeg, S., Lienert, J., Escher, B., Koller, M., Berner, A., Koch, G., Boller, M., 2007. Pilot experiments with electrodialysis and ozonation for the production of a fertiliser from urine. Water Sci. Technol. 56(5), 219-227.

Rauch, W., Brockmann, D., Peters, I., Larsen, T.A., Gujer, W., 2003. Combining urine separation with waste design: an analysis using a stochastic model for urine production. Water Res. 37(3), 681-689. 
Schuwirth, N., Reichert, P., Lienert, J., in preparation. Methodological aspects of multicriteria decision support in environmental management: A case study on pharmaceutical removal from hospital wastewater.

Udert, K.M, Kind, E., Teunissen, M., Jenni, S., Larsen, T.A. 2008. Effect of heterotrophic growth on nitritation/anammox in a single sequencing batch reactor. Water Sci. Technol. 58(2), 277-284.

Udert, K.M., Larsen, T. A., Gujer, W., 2006. Fate of major compounds in source-separated urine. Water Sci. Technol. 54, 11-12, 413-420.

UNEP, 2006. Marine and coastal ecosystems and human well-being: A synthesis report based on the findings of the Millennium Ecosystem Assessment. UNEP. 76 pp. Web download: http://www.unep-wcmc.org/resources/PDFs/Completev6\%20_LR.pdf (accessed 23.06.2010) USDA, 2009. USDA Economics, Statistics and Market Information System. Web access: http://usda.mannlib.cornell.edu/MannUsda/viewDocumentInfo.do;jsessionid=52FA83ED8F0 97991A3FD1C85644A6948?documentID=1003 (accessed 23.06.2010)

WHO, 2006. Guidelines for the safe use of wastewater, excreta and greywater. Volume 4: Excreta and greywater use in agriculture. Chapter 4, World Health Organization, ISBN 924 154685 9. Web download:

http://www.who.int/water_sanitation_health/wastewater/gsuweg4/en/index.html (accessed 23.06.2010)

Wilsenach, J.A., van Loosdrecht, M.C.M., 2006. Integration of processes to treat wastewater and source-separation. J. Environ. Eng.-ASCE 132(3), 331-341.

Yang, W., Vollertsen, J., Hvitved-Jacobsen, T., 2004. Anoxic control of odour and corrosion from sewer networks. Water Sci. Technol. 50(4), 341-349. 
Table 1 Composition of urine (Udert et al., 2006)

- Nitrogen; $\mathrm{N}$ (predominately in form of ammonia/ammonium, $\mathrm{NH}_{3} / \mathrm{NH}_{4}{ }^{+}$)

- Phosphorus (P)

- Potassium (K) and micronutrients

- Unspecific organics (expressed as chemical oxygen demand, COD)

- Organic micropollutants (MP, mainly hormones and pharmaceuticals ${ }^{1}$ )

- Microorganisms (MO, mainly bacteria and viruses)

- Salt (expressed as ionic strength or conductivity)

- Very small amounts of heavy metals

- Water

\footnotetext{
${ }^{1}$ We omit any discussion on residues from cleaning agents because we did no work on this issue.
} 
Table 2 Generalized overview of the different options for urine: removal, recovery, hygienization, separation of micropollutants and removal of micropollutants (see also Figure 2)

\begin{tabular}{|c|c|c|}
\hline & Technologies from Maurer et al., 2006 & Notes \\
\hline REMOVAL & & For efficiencies, see original literature \\
\hline P-removal & Struvite $(I)+$ disposal of struvite ${ }^{*}$ & Struvite (I): without addition of $P$ \\
\hline $\mathrm{NH}_{4}^{+}$-removal & Partial nitrification & Struvite (II): with addition of $\mathrm{P}$ for quantitative recovery of $\mathrm{N}$ \\
\hline N-removal & Partial nitrification + anammox & \multirow[b]{2}{*}{$\begin{array}{l}\text { "Disposal of struvite is not mentioned in the reference, but } \\
\text { may be necessary if fertilizer production is not possible. }\end{array}$} \\
\hline$P$ and N-removal & $\begin{array}{l}\text { Nitrification + denitrification } \\
\text { Struvite }(I I)+\text { disposal of struvite }\end{array}$ & \\
\hline RECOVERY & & Definition of recovery: volume reduction, see reference \\
\hline P-recovery & Struvite (I) & Struvite (I): without addition of $P$ \\
\hline N-recovery & $\begin{array}{l}\mathrm{NH}_{3} \text {-stripping } \\
\text { lon-exchange } \\
\text { Acidification }(l)+\mathrm{IBDU}\end{array}$ & Struvite (II): with addition of $\mathrm{P}$ for quantitative recovery of $\mathrm{N}$ \\
\hline$P$ and N-recovery & $\begin{array}{l}\text { Acldilication }(I)+I B D U \\
\text { Electrodialysis } \\
\text { Struvite (II) } \\
\text { Freeze-thaw } \\
\text { Acidification }(I)+\text { evaporation } \\
\text { Acidification }(I I)+\text { reverse osmosis }\end{array}$ & $\begin{array}{l}\text { Acidification (I; II): only relevant as pre-treatment, for } \\
\text { definitions see OTHER TREATMENTS }\end{array}$ \\
\hline \multirow{5}{*}{$\begin{array}{l}\text { OTHER } \\
\text { TREATMENTS }\end{array}$} & Acidification (I) & Acidification (I): acidification of non-hydrolyzed urine \\
\hline & Acidification (II) & Acidification (II): acidification of hydrolyzed urine \\
\hline & Microfiltration & Microfiltration: hygienization \\
\hline & Acidification $(\mathrm{I})+$ nanofiltration & Nanofiltration: separation of nutrients and micropollutants \\
\hline & Storage & Storage: hygienization \\
\hline
\end{tabular}


Table 3 NoMix STEEPLED factors for generic description of scenarios. We list the factors that may play a role in deciding which NoMix technology should best be chosen in a given scenario. The main state of factors that influence the process engineering objectives are indicated in bold. For explanations see text.

\begin{tabular}{|c|c|c|c|}
\hline NoMix STEEPLED Factors & Main State of Factors ${ }^{1}$ & Process Engineering Objectives (Step 2) & Influence on Criteria Weighting (Step 5) \\
\hline \multicolumn{4}{|l|}{ Social Aspects } \\
\hline A Water scarcity & $\begin{array}{l}\text { A1 No water scarcity } \\
\text { A2 Water scarcity }\end{array}$ & $\begin{array}{l}\text { A2 Is a possible driver for NoMix (see text), but } \\
\text { no decisive influence on step } 2\end{array}$ & $\begin{array}{l}\text { At the moment we see no criteria (Table } 4 \text { ) that } \\
\text { would be influenced by water scarcity }\end{array}$ \\
\hline B Urban hygiene & $\begin{array}{l}\text { B1 Urban hygiene ok } \\
\text { B2 Urban hygiene is a problem }\end{array}$ & $\begin{array}{l}\text { B2 Is a possible driver for NoMix (see text), but } \\
\text { no decisive influence on step } 2\end{array}$ & $\begin{array}{l}\text { At the moment we see no criteria (Table } 4 \text { ) that } \\
\text { would be influenced by urban hygiene }\end{array}$ \\
\hline \multicolumn{4}{|l|}{ Technological Aspects } \\
\hline C Wastewater infrastructure & $\begin{array}{l}\text { C1 Sewers, WWTP, sufficient } \\
\text { nutrient removal }\end{array}$ & & $\begin{array}{l}\text { C1 Solution will have to tackle the problem of } \\
\text { transition management }\end{array}$ \\
\hline \multirow[t]{5}{*}{$\begin{array}{l}\text { (WWTP = } \\
\text { WasteWater Treatment Plant) }\end{array}$} & $\begin{array}{l}\text { C2 Sewers, WWTP, but } \\
\text { insufficient } \mathrm{NH}_{4}^{+}=\text {-removal }\end{array}$ & C2 $\mathrm{NH}_{4}{ }^{+}$-removal will be an objective & $\begin{array}{l}\text { C2 Solution will compete with upgrading of } \\
\text { WWTP }\end{array}$ \\
\hline & $\begin{array}{l}\text { C3 Sewers, WWTP, but } \\
\text { insufficient N-removal }\end{array}$ & C3 N-removal will be an objective & $\begin{array}{l}\text { C3 Solution will compete with upgrading of } \\
\text { WWTP }\end{array}$ \\
\hline & $\begin{array}{l}\text { C4 Sewers, WWTP, but } \\
\text { insufficient P-removal }\end{array}$ & C4 P-removal will be an objective & $\begin{array}{l}\text { C4 Solution will compete with other measures } \\
\text { for P-elimination }\end{array}$ \\
\hline & C5 Sewers, but no WWTP & C5 No influence on step 2 & C5 Solution will compete with new WWTP \\
\hline & C6 No Sewers & C6 No influence on step 2 & C6 Solution will compete with sewers + WWTP \\
\hline D Type of housing and setting & $\begin{array}{l}\text { D1 Single houses } \\
\text { D2 Apartments in dense } \\
\text { settlements } \\
\text { D3 Institutions }\end{array}$ & No influence on step 2 & $\begin{array}{l}\text { The type of housing and setting influences } \\
\text { transport, space requirements, and the relevant } \\
\text { size of a possible on-site technology. D2 and } \\
\text { D3 are to some degree similar, at least from a } \\
\text { technical point of view. }\end{array}$ \\
\hline \multicolumn{4}{|l|}{ Economic Aspects } \\
\hline $\begin{array}{l}\text { E National economy and } \\
\text { resources for (waste) water } \\
\text { management }\end{array}$ & $\begin{array}{l}\text { E1 OECD country } \\
\text { E2 Fast-industrializing country } \\
\text { E3 Developing country }\end{array}$ & No influence on step 2 & $\begin{array}{l}\text { E1 Expensive solutions may be considered } \\
\text { E2 Cost of technology will be a main objective } \\
\text { E3 Only cheap solutions will have a chance }\end{array}$ \\
\hline F Availability of fertilizer & $\begin{array}{l}\text { F1 Nutrient application is not } \\
\text { limited by availability of }\end{array}$ & $\begin{array}{l}\text { F1 Nutrient recycling may or may not be an } \\
\text { objective }\end{array}$ & $\begin{array}{l}\text { F1 Any recycling option has to be competitive } \\
\text { in a global economy (unless overruled by }\end{array}$ \\
\hline
\end{tabular}


Table 3 NoMix STEEPLED factors for generic description of scenarios. We list the factors that may play a role in deciding which NoMix technology should best be chosen in a given scenario. The main state of factors that influence the process engineering objectives are indicated in bold. For explanations see text.

\begin{tabular}{|c|c|c|c|}
\hline \multirow[t]{3}{*}{ NoMix STEEPLED Factors } & Main State of Factors 1 & Process Engineering Objectives (Step 2) & \multirow{3}{*}{$\begin{array}{l}\text { Influence on Criteria Weighting (Step 5) } \\
\text { other criteria, e.g. on an ethical basis) } \\
\text { F2 Any recycling option has to be competitive } \\
\text { in a local economy }\end{array}$} \\
\hline & fertilizer & & \\
\hline & $\begin{array}{l}\text { F2 Nutrient application is } \\
\text { limited by availability of } \\
\text { fertilizer (e.g. due to price) }\end{array}$ & $\begin{array}{l}\text { F2 One would expect nutrient recycling to } \\
\text { be an objective }\end{array}$ & \\
\hline \multicolumn{4}{|l|}{ Ecological Aspects } \\
\hline G. Nutrient emissions & $\begin{array}{l}\mathrm{G} 1 \mathrm{NH}_{4}{ }^{+} \text {is a problem } \\
\text { G2 Nitrogen is a problem } \\
\text { G3 Phosphorus is a problem } \\
\text { G4 Nitrogen and Phosphorus are } \\
\text { not a (perceivable) problem }\end{array}$ & $\begin{array}{l}\text { G1 } \mathrm{NH}_{4}^{+} \text {-removal is an objective } \\
\text { G2 Nitrogen removal will be an objective } \\
\text { G3 Phosphorus removal will be an } \\
\text { objective } \\
\text { G4 Nutrient removal will not be an objective }\end{array}$ & $\begin{array}{l}\text { G1, G2, G3: The criterion 'efficiency' will } \\
\text { probably be important for the ranking of criteria }\end{array}$ \\
\hline \multicolumn{4}{|l|}{ Political Aspects } \\
\hline H. Time frame of politicians & $\begin{array}{l}\text { H1 Politics interested in (fast) } \\
\text { short term solutions } \\
\text { H2 Politics interested in 'best' } \\
\text { solution, even if long term }\end{array}$ & No influence on step 2 & $\begin{array}{l}\text { H1 Minimal solutions will be preferred } \\
\text { H2 Long-term solutions will rank higher (long } \\
\text { term optimization strategy) }\end{array}$ \\
\hline \multicolumn{4}{|l|}{ Legal Aspects } \\
\hline I. Water pollution control & $\begin{array}{ll}\text { I1 } & \text { Targets for } \mathrm{NH}_{4}^{+} \\
\text {12 } & \text { Targets for } \mathrm{N} \\
\text { 13 } & \text { Targets for } \mathrm{P} \\
\text { 14 } & \text { No relevant targets for } \mathrm{N} \text { or } \mathrm{P}\end{array}$ & $\begin{array}{l}\text { I1 } \mathrm{NH}_{4}^{+} \text {-removal is an objective } \\
\text { I2 Nitrogen removal is an objective } \\
\text { I3 Phosphorus removal is an objective } \\
\text { I4 From a legal point of view, nutrient removal } \\
\text { is not an objective }\end{array}$ & $\begin{array}{l}\text { I1, I2, I3, I5: The criterion 'efficiency' will } \\
\text { probably be important for the ranking }\end{array}$ \\
\hline & 15 Targets for MP & I5 MP removal is an objective & $\begin{array}{l}15 \text { We do not know about such targets yet, but } \\
\text { they are a conceivable next step }\end{array}$ \\
\hline J. Fertilizer regulation & $\begin{array}{l}\text { J1 Raw urine allowed } \\
\text { J2 Hygienic requirements } \\
\text { J3 Requirements for organic } \\
\text { micropollutants } \\
\text { J4 No approval possible }\end{array}$ & $\begin{array}{l}\text { J1 No special requirements } \\
\text { J2 If fertilizer: Hygienic requirements } \\
\text { J3 If fertilizer: Requirements for separation } \\
\text { of micropollutants and nutrients } \\
\text { J4 Recycling options not possible }\end{array}$ & $\begin{array}{l}\text { J1 Value of fertilizer may be important } \\
\text { J2 Value of fertilizer may be important } \\
\text { J3 Value of fertilizer may be important }\end{array}$ \\
\hline
\end{tabular}


Table 3 NoMix STEEPLED factors for generic description of scenarios. We list the factors that may play a role in deciding which NoMix technology should best be chosen in a given scenario. The main state of factors that influence the process engineering objectives are indicated in bold. For explanations see text.

\begin{tabular}{|c|c|c|c|}
\hline NoMix STEEPLED Factors & Main State of Factors ${ }^{1}$ & Process Engineering Objectives (Step 2) & Influence on Criteria Weighting (Step 5) \\
\hline & & & J4 Value as raw material may be important \\
\hline \multicolumn{4}{|l|}{ Ethical Aspects } \\
\hline K. Precautionary principle & $\begin{array}{l}\text { K1 Precautionary principle for } \\
\text { micropollutants } \\
\text { K2 Micropollutants are not an } \\
\text { issue }\end{array}$ & $\begin{array}{l}\text { K1 Removal of micropollutants is an } \\
\text { objective } \\
\text { K2 Removal of micropollutants is not an } \\
\text { objective }\end{array}$ & $\begin{array}{l}\text { K1 Societal priority for micropollant removal } \\
\text { determines the acceptable costs for this } \\
\text { option }\end{array}$ \\
\hline \multirow[t]{5}{*}{ L. Sustainability issues } & $\begin{array}{l}\text { L1 Special concern about } \\
\text { limited P-resources }\end{array}$ & L1 P-recycling is an objective & $\begin{array}{l}\text { L1 Societal priority for P-recycling determines } \\
\text { the acceptable costs for this option }\end{array}$ \\
\hline & L2 Limited P-resources 'no' issue & L2 P-recycling is not an objective & \\
\hline & $\begin{array}{l}\text { L3 Special concern about } \\
\text { energy consumption of } \\
\text { current } \mathrm{N} \text {-fixation }\end{array}$ & L3 Nitrogen recycling may be an objective & L3 Energy will be important for the ranking \\
\hline & $\begin{array}{l}\text { L4 'No' concern about energy } \\
\text { consumption of current } \mathrm{N} \text { - } \\
\text { fixation }\end{array}$ & L4 Nitrogen recycling is not an objective & $\begin{array}{l}\text { L4 Energy is probably less important for } \\
\text { ranking than in L3 }\end{array}$ \\
\hline & $\begin{array}{l}\text { L5 Nutrient recycling is } \\
\text { considered necessary for a } \\
\text { sustainable future }\end{array}$ & L5 $\mathrm{P}$ and $\mathrm{N}$ recycling is an objective & $\begin{array}{l}\text { L5 Societal priority for general recycling } \\
\text { determines the acceptable costs for this } \\
\text { option }\end{array}$ \\
\hline \multicolumn{4}{|l|}{ Demographic Aspects } \\
\hline M.Local population growth & $\begin{array}{l}\text { M1 Stagnating population growth } \\
\text { M2 High population dynamics }\end{array}$ & No influence on step 2 & $\begin{array}{l}\text { M1 Adaptation into existing system ranks high } \\
\text { M2 Large scope for implementation in new } \\
\text { developments (adaptation less important) }\end{array}$ \\
\hline
\end{tabular}

\footnotetext{
${ }^{1}$ Factor states that have an impact on treatment decisions are highlighted in bold
} 
Table 4 Stakeholder criteria for evaluating urine processing technologies

\begin{tabular}{|c|c|c|}
\hline & Evaluation Criteria & Explanation / Example \\
\hline \multirow[t]{3}{*}{ Efficiency } & Removal/Recovery efficiency & e.g. for $N, P$ or $M P$ \\
\hline & Separation efficiency & e.g. for nutrients and MP \\
\hline & Hygiene of fertilizer product & Mainly viruses and bacteria \\
\hline \multirow[t]{3}{*}{ Costs } & Development costs & $\begin{array}{l}\text { e.g. what stage is technology } \\
\text { in? Lab- or pilot stage? }\end{array}$ \\
\hline & Investment costs & \\
\hline & Operation and Maintenance & $\begin{array}{l}\text { e.g. Energy, material, } \\
\text { maintenance }\end{array}$ \\
\hline \multirow[t]{3}{*}{ Operation } & Existing Experience & \\
\hline & Robustness & $\begin{array}{l}\text { A system ... may be said to be } \\
\text { 'robust' if it is capable of } \\
\text { coping well with variations } \\
\text { (sometimes unpredictable } \\
\text { variations) in its operating } \\
\text { environment with minimal } \\
\text { damage, alteration or loss of } \\
\text { functionality (Wikipedia) }\end{array}$ \\
\hline & Operational safety & $\begin{array}{l}\text { For staff; e.g. with respect to } \\
\text { hygiene and other health } \\
\text { hazards }\end{array}$ \\
\hline \multirow[t]{2}{*}{ Environmental impacts ${ }^{1}$} & Energy demand & \\
\hline & Other environmental impacts & $\begin{array}{l}\text { Usage of non-renewable } \\
\text { resources, chemicals, or } \\
\text { harmful material or release of } \\
\text { such substances to the } \\
\text { environment (e.g. leaking of } \\
\text { ammonia to atmosphere) }\end{array}$ \\
\hline Value of products ${ }^{1}$ & Value of product & $\begin{array}{l}\text { e.g. is there a foreseeable } \\
\text { demand / market for this kind } \\
\text { of product? Is it attractive or } \\
\text { disgusting (bad smell, etc.)? }\end{array}$ \\
\hline \multirow[t]{2}{*}{ Systems compliance } & Flexibility & $\begin{array}{l}\text { e.g. is a combination of NoMix } \\
\text { technology with existing } \\
\text { central WWTP possible? }\end{array}$ \\
\hline & Scalability and size & $\begin{array}{l}\text { e.g. can the same technology } \\
\text { be used in different settings } \\
\text { (e.g. in single households and } \\
\text { apartment building)? }\end{array}$ \\
\hline
\end{tabular}

1 The original list from our practice partners included the environmental impacts with respect to water pollution control and the value of the product with respect to nutrient content. Since both of these qualities were included in the initial decision procedure, they are not repeated here.

Because the distinction between step 2 (process engineering objectives) and step 4 (ranking according to criteria) is purely pragmatic, elements can be freely swapped. 


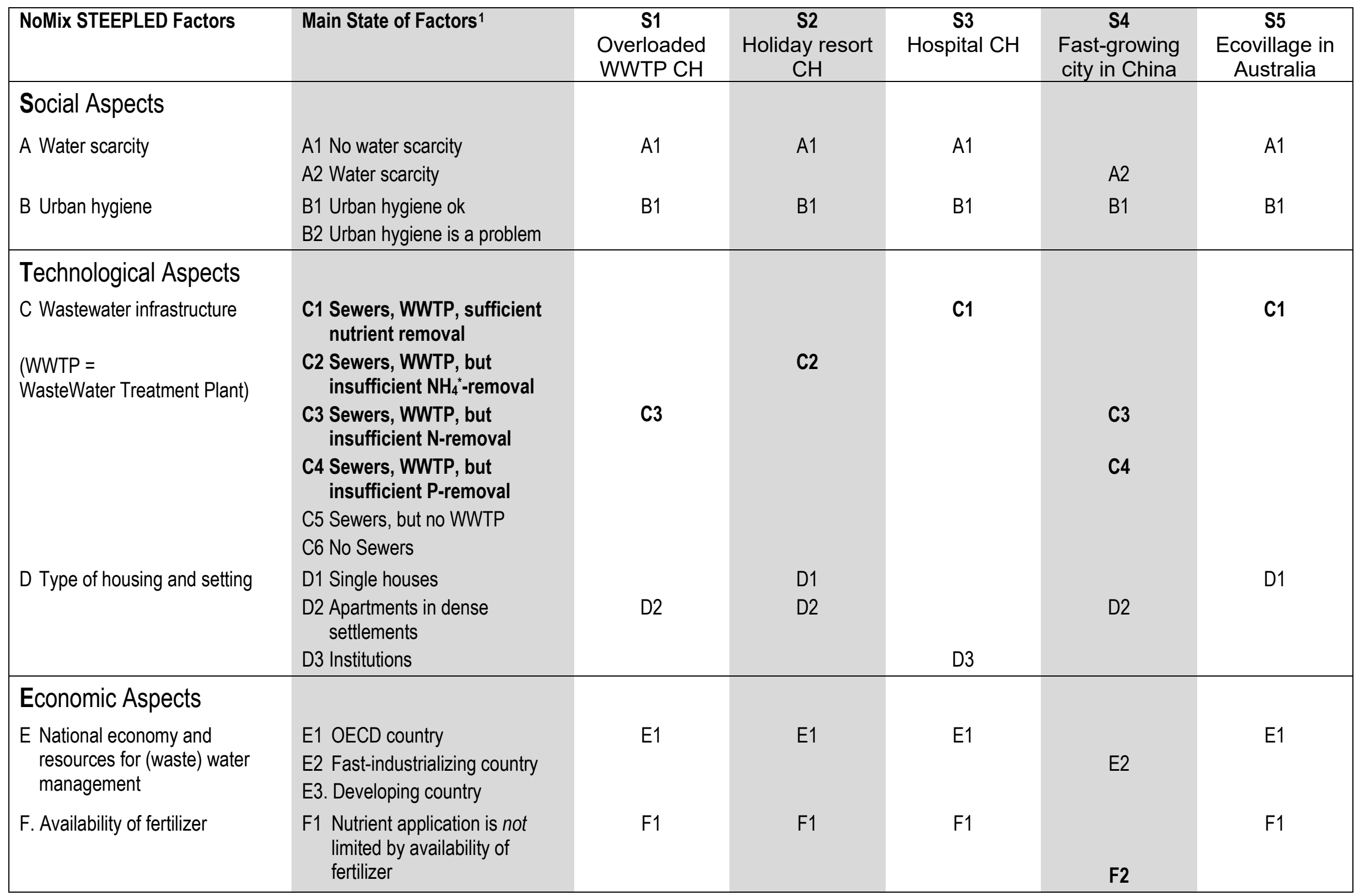




\begin{tabular}{|c|c|c|c|c|c|c|}
\hline NoMix STEEPLED Factors & Main State of Factors ${ }^{1}$ & $\begin{array}{c}\text { S1 } \\
\text { Overloaded } \\
\text { WWTP CH }\end{array}$ & $\begin{array}{c}\text { S2 } \\
\text { Holiday resort } \\
\mathrm{CH} \\
\end{array}$ & $\begin{array}{c}\text { S3 } \\
\text { Hospital } \mathrm{CH}\end{array}$ & $\begin{array}{c}\text { S4 } \\
\text { Fast-growing } \\
\text { city in China } \\
\end{array}$ & $\begin{array}{c}\text { S5 } \\
\text { Ecovillage in } \\
\text { Australia } \\
\end{array}$ \\
\hline & $\begin{array}{l}\text { F2 Nutrient application is } \\
\text { limited by availability of } \\
\text { fertilizer } \\
\text { (e.g. due to price) }\end{array}$ & & & & & \\
\hline \multicolumn{7}{|l|}{ Ecological Aspects } \\
\hline \multirow[t]{4}{*}{ G. Nutrient emissions } & G1. $\mathrm{NH}_{4}{ }^{+}$is a problem ${ }^{2}$ & & G1 & & & \\
\hline & G2. Nitrogen is a problem & & & & G2 & G2 \\
\hline & G3. Phosphorus is a problem & & & & G3 & G3 \\
\hline & $\begin{array}{l}\text { G4. Nitrogen and Phosphorus are } \\
\text { not a (perceivable) problem }\end{array}$ & G4 & & G4 & & \\
\hline \multicolumn{7}{|l|}{ Political Aspects } \\
\hline \multirow[t]{2}{*}{ H. Time frame of politicians } & \multirow{2}{*}{$\begin{array}{l}\text { short term solutions } \\
\text { H2 Politics interested in 'best' } \\
\text { solution, even if long term }\end{array}$} & & $\mathrm{H} 1$ & & $\mathrm{H} 1$ & $\mathrm{H} 1$ \\
\hline & & $\mathrm{H} 2$ & & $\mathrm{H} 2$ & & $\mathrm{H} 2$ \\
\hline \multicolumn{7}{|l|}{ Legal Aspects } \\
\hline \multirow[t]{5}{*}{ I. Water pollution control } & I1 Targets for $\mathrm{NH}_{4}^{+}$ & 11 & 11 & & & \\
\hline & 12 Targets for $\mathrm{N}$ & 12 & & 12 & 12 & 12 \\
\hline & 13 Targets for $P$ & 13 & 13 & 13 & 13 & 13 \\
\hline & I4 No relevant targets for $\mathrm{N}$ or $\mathrm{P}$ & & & & & \\
\hline & 15 Targets for MP3 & & & & & \\
\hline \multirow[t]{3}{*}{ J. Fertilizer regulation } & J1 Raw urine allowed & & & & J1 & \\
\hline & J2 Hygienic requirements & J2 & J2 & J2 & & \\
\hline & $\begin{array}{l}\text { J3 Requirements for organic } \\
\text { micropollutants }\end{array}$ & J3 & J3 & J3 & & J3 \\
\hline
\end{tabular}




\begin{tabular}{|c|c|c|c|c|c|c|}
\hline NoMix STEEPLED Factors & Main State of Factors ${ }^{1}$ & $\begin{array}{c}\text { S1 } \\
\text { Overloaded } \\
\text { WWTP CH }\end{array}$ & $\begin{array}{c}\text { S2 } \\
\text { Holiday resort } \\
\mathrm{CH}\end{array}$ & $\begin{array}{c}\text { S3 } \\
\text { Hospital } \mathrm{CH}\end{array}$ & $\begin{array}{c}\text { S4 } \\
\text { Fast-growing } \\
\text { city in China } \\
\end{array}$ & $\begin{array}{c}\text { S5 } \\
\text { Ecovillage in } \\
\text { Australia } \\
\end{array}$ \\
\hline \multicolumn{7}{|l|}{ Ethical Aspects } \\
\hline \multirow[t]{2}{*}{ K. Precautionary principle } & $\begin{array}{l}\text { K1 Precautionary principle for } \\
\text { micropollutants }\end{array}$ & $\mathrm{K} 1$ & & K1 & & $\mathrm{K} 1$ \\
\hline & $\begin{array}{l}\text { K2 Micropollutants are not an } \\
\text { issue }\end{array}$ & & $\mathrm{K} 2$ & & $\mathrm{~K} 2$ & \\
\hline \multirow[t]{6}{*}{ L. Sustainability issues } & $\begin{array}{l}\text { L1 Special concern about } \\
\text { limited P-resources }\end{array}$ & & & $\mathrm{L} 14$ & & \\
\hline & L2 Limited P-resources 'no' issue & $\mathrm{L} 2$ & $\mathrm{~L} 2$ & & $\mathrm{~L} 2$ & $\mathrm{~L} 2$ \\
\hline & L3 Special concern about & & & $\mathrm{L}^{4}$ & & L3 \\
\hline & energy & L4 & L4 & & L4 & \\
\hline & $\begin{array}{l}\text { L4 'No' concern about energy } \\
\text { consumption of current } \\
\text { ammonia production }\end{array}$ & & & & & \\
\hline & $\begin{array}{l}\text { L5 Nutrient recycling is } \\
\text { considered necessary for a } \\
\text { sustainable future }\end{array}$ & & & & & L5 \\
\hline \multicolumn{7}{|l|}{ Demographic Aspects } \\
\hline \multirow[t]{2}{*}{ M. Local population growth } & M1 Stagnating population growth & & M1 & M1 & & \\
\hline & M2 High population dynamics & M2 & & & M2 & M2 \\
\hline
\end{tabular}

${ }^{1}$ Factor states that have an impact on treatment decisions are highlighted in bold

${ }^{2}$ We offer no specific definition of the word 'problem'. As opposed to the legal aspects, which can be objectively stated, the definition of 'problems' is in many cases subject to interpretation by the involved stakeholders.

${ }^{3}$ At the moment, we are not aware of any place where targets for micropollutants are implemented. This could however alter rapidly, showing that the suggested framework will have to be continuously adapted in a changing world.

${ }^{4}$ Although the stakeholders started out with an earnest concern about limited P-resources and energy for N-production, on-going interviews with the stakeholders revealed that in the meantime, the aspect of micropollutants took over as the main motivation. The schematic representation of the different stakeholder positions helps to clarify such positions. 
Table 6: Qualitative comparison of three technologies considered for Scenario 1.

\begin{tabular}{|c|c|c|c|}
\hline & $\begin{array}{l}\text { Nitrification / } \\
\text { Denitrification }\end{array}$ & $\begin{array}{l}\text { Partial nitrification / } \\
\text { Anammox }\end{array}$ & $\begin{array}{l}\mathrm{NH}_{3} \text {-stripping } \\
\text { (without pH correction) }\end{array}$ \\
\hline \multicolumn{4}{|l|}{ Efficiency } \\
\hline N-Removal efficiency & $>90 \%$ & $>90 \%$ & No experience yet \\
\hline Hygiene of product & No fertilizer product & No fertilizer product & Excellent \\
\hline \multicolumn{4}{|l|}{ Costs } \\
\hline Development costs & $\begin{array}{l}\text { Fully developed } \\
\text { (digester supernatant) }\end{array}$ & $\begin{array}{l}\text { First full scale plants } \\
\text { (digester supernatant) }\end{array}$ & Under development \\
\hline Investment costs & small & small & not known \\
\hline Operation & Methanol & No chemicals & Sulfuric acid \\
\hline Maintenance & Not time consuming & Potential time consuming & not known \\
\hline \multicolumn{4}{|l|}{ Operation } \\
\hline Operational safety & No problem & No problem & $\begin{array}{l}\text { Sulfuric acid and } \\
\text { gaseous } \mathrm{NH}_{3} \text { may be a } \\
\text { problem }\end{array}$ \\
\hline Existing Experience & Much & Little & None \\
\hline Robustness & Good & Problematic & Should be good \\
\hline \multicolumn{4}{|l|}{ Environ. impacts } \\
\hline Energy demand & Low & Lower & Requires (excess) heat \\
\hline Other environ. impacts & None & None & Chemicals \\
\hline Value of products & No product & No product & High \\
\hline \multicolumn{4}{|l|}{ Systems compliance. } \\
\hline Flexibility & \multicolumn{3}{|c|}{$\begin{array}{l}\text { All three technologies have about the same degree of flexibility, because they } \\
\text { can be installed at the treatment plant for nitrogen removal from sludge } \\
\text { supernatant and gradually take up urine that may even be transported through } \\
\text { the existing sewer network at night (ref.) }\end{array}$} \\
\hline Scalability and size & $\begin{array}{l}\text { Only central; dosing of } \\
\text { methanol in an on-site } \\
\text { setting is not conceivable }\end{array}$ & $\begin{array}{l}\text { At the moment only } \\
\text { central; optimization for } \\
\text { on-site application is } \\
\text { running }\end{array}$ & $\begin{array}{l}\text { At the moment only } \\
\text { central }\end{array}$ \\
\hline
\end{tabular}

